\title{
PENGARUH KECERDASAN INTELEKTUAL, KECERDASAN EMOSIONAL, DAN KECERDASAN SPIRITUAL TERHADAP KINERJA WIRAUSAHA MUSLIM DI KABUPATEN PURWAKARTA
}

\author{
Ismail Ludin \\ Suherman Saleh \\ Dedeng Abdul Gani Amruloh \\ Prodi Manajemen - STIE DR. KHEZ MUTTAQIEN PURWAKARTA \\ ismailludin70@gmail.com \\ Prodi Manajemen - STIE DR. KHEZ MUTTAQIEN PURWAKARTA \\ suherman.saleh@gmail.com \\ Prodi Manajemen - STIE DR. KHEZ MUTTAQIEN PURWAKARTA \\ Dedeng.amrullah@gmail.com
}

\begin{abstract}
Islam is a comprehensive religion. Islam is not only discussing about the dimension of ukhrowi (hereafter) but also world. One of that dimension is practicing of entrepreneur. Practicing of entrepreneur is one of the way to get a performance's successful. In Islamic perspective, the success of muslimpreneur performance is associated in word of Al falah. Al falah is a success concept for muslimpreneur in the world and hereafter. There are many factors that affect the success of muslimpreneur performance. Human intelligent as the main factor surrounding of that.

According to the phenomenon, this research aims to examine the effect of intellectual, emotional, and spiritual quotient toward the muslimpreneur performance. This research used descriptive analityc method. The population of this research is the Islamic small entreprise in Purwakarta regent with 86 number of samples. Double-linier-regression is used as analysis instrument. Library and field research as the dimension of research through questionnaire.

The result of this research indicates first, partially, the muslimpreneur performance is insignificantly affected by intellectual and emotional quotient variable. Only the spiritual quotient that significantly affects toward the muslimpreneur perfomance. Second, simultanously, the muslimpreneur performance is significantly affected by the variable of intellectual, emotional, and spiritual quotient. This research is limited in independend variable. Exploring the most essential independen variable should be done in order to get better result.
\end{abstract}

Keywords : Intelellectul quotient, emotional quotient, spiritual quotient, muslimpreneur performance, and Al falah. 


\section{Pendahuluan}

Islam merupakan sebuah agama yang sempurna dan komprehensif. Islam merupakan agama yang identik dengan sebuah usaha. Sesuai dengan firman-Nya dalam QS. AlMaidah (5:3) yang berbunyi :

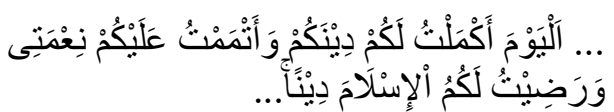

“... Pada hari ini telah kusempurnakan untuk kamu agamamu, dan telah Ku-cukupkan nikmat-Ku, dan telah Ku-ridhai Islam itu jadi agama bagimu”.

Di dalam konteks kehidupan, ayat tersebut dapat menjelaskan bahwa makna "kesempurnaan" dalam Islam meliputi seluruh aspek kehidupan manusia. Termasuk di dalamnya urusan usaha. Harapan manusia menjalani kehidupan yaitu ingin mendapatkan keberhasil-an. Salah satu cara untuk mencapai keberhasil-an dalam menjalankan kehidupan yaitu dengan menjadi seorang wirausaha. Karena berwira-usaha akan mendorong manusia untuk dapat mencapai sebuah keberhasilan.

Agama Islam sangat mendorong muslim untuk menjadi pengusaha dalam rangka mencari rizki. Di dalam hadits yang diriwayat-kan oleh Athirmidzi dalam Dedeng (2016:1) yang berbunyi :

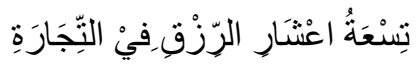

"9 dari 10 pintu rizki ada dalam perdagangan"

Berdagang merupakan aktivitas ekonomi yang memiliki kedudukan yang paling mulia di sisi Allah SWT. Di dalam hadits Rosulullah SAW yang lain yang diriwayatkan oleh Al Bazzar dalam Aprijon (2013:9) yang berbunyi :

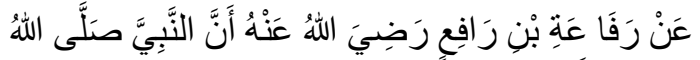

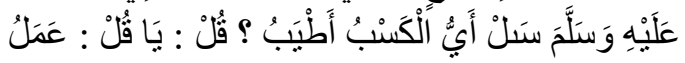

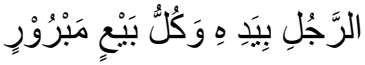

"Mata pencaharian apakah yang paling baik, ya Rosulullah? "jawab Beliau : ialah seorang yang bekerja dengan tangannya sendiri dan setiap jual beli yang bersih"

Berkaitan dengan wirausaha, maka kinerja merupakan salah satu ukuran dalam me-nentukan keberhasilan seseorang atau sebuah perusahaan dalam menjalankan bisnisnya. Seseorang yang menjalankan sebuah usaha tentunya ingin berhasil. Kinerja ini menentukan hasil yang akan didapat setelah melalui proses usaha yang panjang. Proses usaha yang sesuai dengan aturan Islam akan menghasilkan kinerja yang baik dan begitu sebaliknya proses usaha yang tidak sesuai dengan atur-an Islam akan menghasilkan kinerja yang buruk.

Saat ini peradaban manusia terus mengalami perubahan seiring mengikuti perkembangan zaman. Perubahan ini menuntut manusia untuk terus berpikir dan berusaha keras dalam rangka mempertahankan keeksistensian dirinya dan bertahan dalam rangka mencapai keberhasilan hidup masingmasing. Manusia yang memiliki kemampuan menerima dan menang-gapi perubahan dengan baik inilah yang akan mampu bertahan dan menemukan arti keberhasilan yang sesungguhnya bagi hidupnya.

Di tengah kondisi zaman seperti ini, wirausaha muslim pun menjadi sorotan yang sangat menarik dalam hal memandang perubahan zaman. Ketidakpastian kondisi saat ini mempengaruhi kinerja wirausaha muslim itu sendiri. Mereka terombang ambing dalam kondisi tidak pasti. Kinerja usahanya mengalami fluktuasi. Dari perspektif Islam, kondisi fluktuatif ini dipandang lebih dari sekedar urusan finansial/materi melainkan menyangkut keberhasilan kinerjanya dari dimensi moral dan religiusitas.

Saat ini banyak wirausaha yang beragama Islam tetapi dalam praktek wirausahanya mereka jauh dari aturan $\mathrm{Al}$ Quran dan Sunnah yang seharusnya dilakukan. Mereka jauh dari nilai-nilai spirit Islam yang seharusnya mampu menjaga amanah dan tanggung jawab dari Allah SWT. Sebagian besar masih terbelenggu dalam sistem ekonomi non muslim sehingga tidak mampu membedakan antara halal dan haram. Seperti yang disampaikan oleh Aminuddin, dkk (2016) dalam penelitiannya bahwa hal-hal seperti ini akan mem-bawa kesesatan tujuan usaha bagi wirausaha muslim.

Dalam perspektif Islam, ukuran keberhasilan kinerja wirausaha muslim tidak hanya 
diukur dari dimensi materi atau finansial saja melainkan sejauh mana ia mampu mencapai keberhasilan yang tinggi dari Allah SWT. Dalam perspektif Islam, makna keberhasilan kinerja wirausaha muslim ini disebut Al-Falah. Al-Falah merupakan suatu bentuk keberhasilan yang didapatkan oleh manusia baik di dunia maupun di akhirat.

Ada faktor penting yang sangat mendorong manusia untuk bisa mencapai Al-Falah tersebut. Faktor tersebut adalah kecerdasan manusia. Seperti yang disampaikan oleh Gardner (1983) dalam Mahmood, dkk (2015) bahwa manusia memiliki multi kecerdasan yang bertingkat yaitu kecerdasan intelektual, kecerdasan emosional, dan kecerdasan spiritual.

\section{Tujuan Penelitian}

Penelitian yang dilakukan ini memiliki tujuan yaitu untuk menguji bagaimana pengaruh variabel kecerdasan intelektual, kecerdasan emosional, dan kecerdasan spiritual terhadap kinerja wira-usaha muslim baik secara parsial maupun simultan.

\section{Metodologi Penelitian}

Deskriptif verifikatif merupakan metode yang digunakan dalam penelitian ini. Penelitian ini menggunakan kuesioner sebagai instrumen penelitian. Teknik analisis yang digunakan adalah analisis regresi linier berganda. Ada dua buah pengujian dalam penelitian ini. Pertama uji instrumen atau data melalui uji validitas, reliabilitas, normalitas, dan multi-kolinieritas. Kedua uji hipotesis melalui uji t dan uji $\mathrm{F}$.

\section{Literature Review dan Hipotesis}

Banyak ahli yang mendefinisikan tentang wirausaha muslim. Wirausaha muslim dalam perspektif Islam yang disampaikan oleh Nazamul Hoque, dkk (2013:131) yaitu "Islamic entrepreneur is a person who starts and manages business entreprise following the guidelines of Islam". Pendapat tersebut dapat disederhanakan bahwa wirausaha muslim merupakan seseorang yang memulai dan mengelola usaha berdasarkan aturan Islam.
Wirausaha muslim dalam menjalankan bisnisnya sangat menjauhkan diri dari halhal yang diharamkan oleh Allah SWT. Bagi wirausaha muslim, profit bukan menjadi satusatunya tujuan dalam berwira-usaha melainkan meraih ridho Allah SWT lah yang paling utama.

Pendapat lain disampaikan oleh Salwa, dkk (2013:62) bahwa "Muslimpreneur is someone who perceives an opportunity and create an organization to persue it". Secara sederhana, definisi ini menjelaskan bahwa seorang wirausaha muslim memiliki kemampuan untuk membaca peluang dan sumber daya yang ada, kemudian memanfaatkan dan mengembangkannya sehingga mampu menciptakan bisnis atau produk yang kreatif dan inovatif.

Berkaitan dengan bisnis yang dijalankan oleh pengusaha muslim, maka kinerja merupakan salah satu ukuran yang digunakan untuk melihat apakah bisnis yang dijalankan telah berhasil atau gagal. Kinerja merupakan serangkaian kegiatan manajemen yang memberikan gambaran sejauh mana hasil yang telah dicapai dalam melaksanakan tugas dan tanggung jawabnya dalam bentuk akuntabilitas publik baik berupa keberhasilan maupun kekurangan yang tejadi. Gibson, Ivancevich, dan Donelly (1989) dalam Ani (2010:226). Dari definisi di atas, keberhasilan kinerja ini menitik beratkan pada usaha yang dijalankan sebelum-nya.

Dalam perspektif Islam, kinerja lebih diasosiasikan kedalam makna keberhasilan. Makna keberhasilan sendiri dalam Islam dikenal dengan istilah Al-Falah. Hammat (1992) dalam Dedeng (2016) dan Salwa, dkk (2013) merefleksikan Al falah ke dalam lima komponen yaitu halal (berdasarkan syariat Islam), qona'ah (merasa cukup), taufik (keberkahan dari Allah dalam suatu harapan), sa'adah (kebahagiaan), dan jannah (surga).

Pengukuran keberhasilan wirausaha muslim hanya dapat diukur dengan pendekatan 
moral. Karena konsep Al-Falah ini mengukur keberhasilan pengusaha muslim dari sisi mora dan religiusitasnya. Maka dari itu, Hammat (1992) dalam Dedeng (2016:5) dan Aminuddin, dkk (2016:9) merepresentasikan dimensi dan indikator $\mathrm{Al}$ Falah wirausaha muslim yaitu pertama komitmen religi individu, indikatornya meliputi solat, puasa, membaca Al Quran. Kedua nilai-nilai Islam, indikatornya meliputi qonaah (merasa cukup), halal, tanggung jawab, ber-syukur. Ketiga bisnis outcome, indikator-nya meliputi zakat dan tanggung jawab sosial.

Berkaitan dengan kinerja wirausaha muslim, untuk mencapai sebuah keberhasilan kinerjanya maka pengusaha muslim dibekali dengan kecerdasan. Kecerdasan ini mendorong pengusaha muslim untuk memiliki multi kemampuan dalam menjalankan bisnis. Seperti yang disampaikan oleh Gardner (1983) dalam Mahmood, dkk (2015) bahwa manusia memiliki kecerdasan majemuk (Multi Intelligent). Kecerdasan manusia ini meliputi kecerdasan intelektual, kecerdasan emosional, dan kecerdasan spiritual.

Konsep kecerdasan intelektual digagas kali pertama oleh William Stern pada tahun 1912. Mahmood, dkk (2015:554) merujuk pada Pan (2006), Killic (2015), dan Bell (2014) bahwa kecerdasan intelektual dijadikan sebagai tahap pertama dalam membangun kinerja usaha yang baik, karena di dalamnya mengandung unsur berpikir yang kreatif. Pemikiran yang kreatif ini terbentuk dari wawasan dan pengalaman luas.

Beberapa orang beranggapan bahwa kecerdasan intelektual adalah kecerdasan yang mutlak berasal dari manusia sejak lahir. Kecerdasan intelektual setiap orang berbedabeda. Mereka memiliki tingkat nilai IQ yang berbeda-beda. Pada dasarnya nilai IQ seseorang tidak berubah akan berubah sampai dewasa. Adapun yang berubah adalah tingkat ketajaman analisis dan daya pikir.
Jika dilihat dari perspektif Islam, landasan kecerdasan intelektual ini terdapat pada QS. As Sajdah (32:9). Dalam versi Al Quran ini, Allah SWT telah memberikan "pendengaran" dan "penglihatan". Artinya seorang wirausaha muslim yang memiliki kemampuan mendengar dan melihat ini akan pandai melihat segala peluang yang ada dan memanfaatkan peluang tersebut sehingga bisa menciptakan inovasi produk dan terobosan baru dalam bisnisnya.

Merujuk pada ahli yakni Sternbeg dalam Dwiyanti (2009) dalam Masyitah (2014:5) bahwa dimensi dan indikator intelektual yaitu pertama kemampuan memecahkan masalah, indikatornya meliputi mampu memecahkan masalah secara optimal dan me-nunjukan pikiran yang jernih. Kedua intelegensi verbal, indikatornya meiputi memiliki kecakapan yang baik, membaca dengan penuh pemahaman, dan menunjukkan sikap keingintahuan. Ketiga intelegensi praktis, indikatornya meliputi tahu situasi, tahu cara mencapai tujuan, sadar terhadap dunia sekeliling, dan menunjukan minat terhadap dunia luar.

Kecerdasan kedua yaitu kecerdasan emosional. Konsep kecerdasan emosional Daniel Goleman lebih banyak digunakan. Kecerdasan emosisonal juga berkaitan dengan seorang pengusaha muslim. Seperti yang pernah disampaikan Goleman (2002) dalam Mahmood, dkk (2015:554) bahwa "While examining the affect of emotions on the performance of organization finds that $E Q$ helps in reducing the conflict organization and resultantly increase the employee's performance. The success and failure of an organization can be determined by the emotional tone set by the executive interpersonal".

Kecerdasan emosional ini bersentuhan dengan jiwa dan perasaan manusia. Kecerdasan ini lebih meng- utamakan sebuah integritas orang untuk terus bekerjasama. Seperti yang disampai-kan oleh Nachiappan, 
dkk (2014:894) bahwa "Emotional quotient defines the abilities understand emotion, generation of emotion to help thinking, understand emotion, knowledge emotion and emotion control to encourage the growth of intellectual and emotional".

Definisi di atas dapat disederhanakan bahwa kecerdasan emosional mendefinisikan kemampuan untuk memahami emosi, pengetahuan emosi, dan pengendalian emosi dalam membantu mendorong pertumbuhan kecerdasan emosional dan intelektual.

Mengacu pada Goleman dalam Mishra dan Vashist (2014:16) bahwa dimensi dan indikator yang menunjukan kecerdasan emosional yaitu pertama kesadaran diri. Indikatornya meliputi merefleksikan kepercayaan diri, kesadaran emosi diri, penilaian terhadap diri secara nyata, kesenangan diri. Kedua kontrol diri, indikatornya meliputi merefleksikan sifat dapat dipercaya, kewaspadaan, adaptibilitas, kendali diri, dan inovasi. Ketiga motivasi, indikatornya meliputi komitmen, inisiatif, dan optimisme. Keempat empati, indikatornya merefleksikan pemahaman mengenai perasaan orang lain, orientasi pelayanan, dan mengatasi keragaman.

Konsep kecerdasan selanjutnya yaitu spiritual. Kecerdasan spiritual banyak dimaknai oleh para ahli. Salah satunya dalam disertasi Abdul Jalil (2012:9) bahwa merupakan kecerdasan untuk kecerdasan spiritual me-nangkap sebuah perilaku yang ditandai dengan kemampuan untuk mentransendensikan yang fisik dan material, kemampuan untuk meng-alami tingkat kesadaran yang memuncak, kemampuan untuk mensakralkan pengalaman sehari-hari, kemampuan untuk menggunakan sumbersumber spiritual dalam me-nyelesaikan masalah, kemampuan untuk berbuat baik, menunjukan kasih sayang dan kebijaksanaan.
Pendapat lain disampaikan oleh para ahli yakni Zohar dan Marshall (2001) bahwa kecerdasan spiritual merupakan kecerdasan yang bertumpu pada bagian dalam diri manusia. Kecerdasan ini bersentuhan dengan kearifan di luar ego atau jiwa sadar. Kecerdasan spiritual tidak hanya berhubungan dengan nilai-nilai realitas, tetapi juga berhubungan dengan nilai-nilai sakral manusia yang mampu membangkit-kan dan menyadarkan eksistensi dirinya se-bagai makhluk Allah SWT (Ani, 2010:226).

Kecerdasan spiritual merupakan kecerdasan tingkat akhir seorang wirausaha muslim. Karena kecerdasan ini berada dalam titik paling dalam pada hati manusia yang berfungsi secara holistik. Seorang wirausaha muslim berpasrah diri dan mengembalikan lagi segala urusan hidupnya kepada Allah SWT. Seperti yang disampaikan oleh Zohar dan Marshall (2000) dalam Mahmood, dkk (2015:554) bahwa kecerdasan spiritual disebut "Ultimate Intelligence" yaitu kecerdasan yang memiliki posisi tertinggi setelah kecerdasan emosional dan intelektual.

Merujuk pada Zohar \& Marshall (2007) dan Stephen Covey (2004) dalam Misrha dan Vashist (2014:17-19) bahwa dimensi dan indikator kecerdasan spiritual yaitu pertama fleksibilitas, indikatornya meliputi menempat-kan diri dan terbuka menerima saran. Kedua visi hidup, indikatornya meliputi tujuan hidup, prinsip, dan pegangan hidu. Ketiga puncak kesadaran, indikatornya meliputi kesadaran diri. Keempat kemampuan untuk menghadapi dan memanfaatkan penderitaan, Indikatornya meliputi ketenangan batin, tidak ada penyesalan, dan, selalu berdoa. Kelima penggunaan sumber spiritual dalam menyelesaikan masal. 


\section{Hasil dan Pembahasan}

Berdasarkan hasil pengujian-pengujian yang dilakukan pada instrumen dan hipotesis penelitian, maka hasil pengujian ini menunjukkan sebagai berikut :

Tabel 1

Hasil Uji Validitas

\begin{tabular}{|c|c|c|c|}
\hline Variabel & $\begin{array}{c}\mathrm{r} \\
\text { hitung }\end{array}$ & $\begin{array}{c}\mathrm{r} \text { tabel } \\
5 \%(86)\end{array}$ & Keterangan \\
\hline $\mathrm{X} 1$ & 0,607 & 0,207 & Valid \\
\hline $\mathrm{X} 2$ & 0,517 & 0,207 & Valid \\
\hline $\mathrm{X} 3$ & 0,571 & 0,207 & Valid \\
\hline $\mathrm{Y}$ & 0,627 & 0,207 & Valid \\
\hline
\end{tabular}

Berdasarkan hasil uji validitas di atas (Tabel 1) menunjukan bahwa semua nilai $r$ hitung $>r$ tabel dengan nilai signifikansi $5 \%$. Maka dari itu, semua butir pernyataan setiap variabel $\mathrm{X}$ dan $\mathrm{Y}$ dalam kuesioner sebagai instrumen penelitian dianggap valid dan layak untuk digunakan.

Tabel 2

Hasil Uji Reliabilitas

\begin{tabular}{|c|c|c|c|}
\hline Variabel & $\begin{array}{c}\mathrm{r} \\
\text { Alpha }\end{array}$ & $\begin{array}{c}\mathrm{r} \\
\text { tabel }\end{array}$ & Keterangan \\
\hline $\mathrm{X} 1$ & 0,751 & 0,6 & Reliabel \\
\hline $\mathrm{X} 2$ & 0,729 & 0,6 & Reliabel \\
\hline $\mathrm{X} 3$ & 0,732 & 0,6 & Reliabel \\
\hline $\mathrm{Y}$ & 0,754 & 0,6 & Reliabel \\
\hline
\end{tabular}

Berdasarkan hasil uji reliabilitas

(Tabel 2) dapat diketahui bahwa nilai r Alpha $>\mathrm{r}$ tabel. Maka dari itu instrumen penelitian ini dapat dikatakan sangat handal (reliabel).

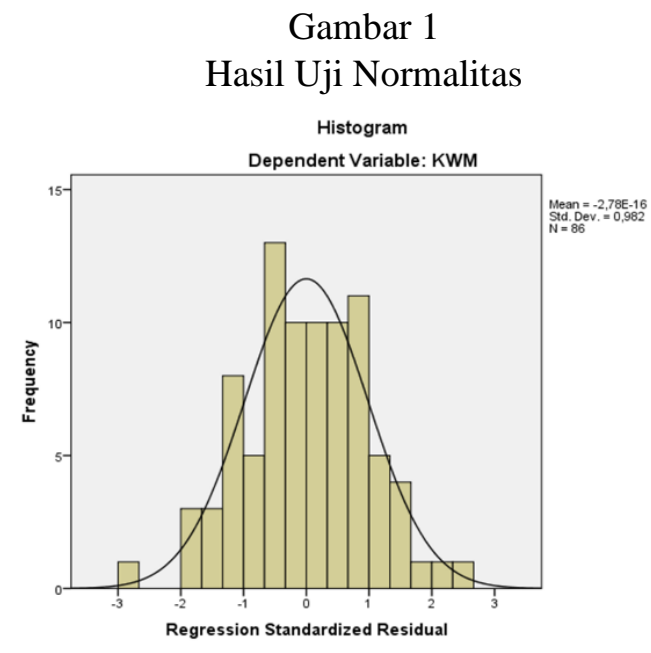

Berdasarkan gambar di atas (Gambar 1), dapat dilihat nilai residual yang diplotkan atau divisualisasikan dalam bentuk grafik. Bentuk grafik histogram tersebut memiliki pola tidak merata (kurtosis positif) yang artinya data berdistribusi normal.

Tabel 3

Hasil Uji Multikolinieritas

\begin{tabular}{|c|c|c|c|}
\hline Variabel & $\begin{array}{c}\text { Tole } \\
\text { rance }\end{array}$ & VIF & Keterangan \\
\hline X1 & 0,658 & 1,519 & $\begin{array}{c}\text { Tidak } \\
\text { Terjadi } \\
\text { Multikorelasi }\end{array}$ \\
\hline X2 & 0,428 & 2,338 & $\begin{array}{c}\text { Tidak } \\
\text { Terjadi } \\
\text { Multikorelasi }\end{array}$ \\
\hline X3 & 0,482 & 2,073 & $\begin{array}{c}\text { Tidak } \\
\text { Terjadi } \\
\text { Multikorelasi }\end{array}$ \\
\hline
\end{tabular}

Dari ringkasan tabel di atas (Tabel 3), dapat diketahui bahwa semua nilai tolerance $0,658,0,428,0,482>0,10$. Nilai VIF 1,519, 2,338, 2,073 < 10. Maka dapat disimpulkan bahwa tidak terjadi multikorelasi antar variabel bebas. 
Tabel 4

Coefficients $^{\mathrm{a}}$

\begin{tabular}{|c|c|c|c|c|c|c|}
\hline \multirow{2}{*}{\multicolumn{2}{|c|}{ Model }} & \multicolumn{2}{|c|}{$\begin{array}{c}\text { Unstandardized } \\
\text { Coefficients }\end{array}$} & \multirow{2}{*}{$\begin{array}{c}\text { Standardized } \\
\text { Coefficients } \\
\text { Beta } \\
\end{array}$} & \multirow{2}{*}{$\mathrm{T}$} & \multirow[b]{2}{*}{ Sig. } \\
\hline & & $\mathrm{B}$ & Std. Error & & & \\
\hline \multirow[t]{4}{*}{1} & (Constant) & 6,246 & 3,600 & & 1,735 & ,087 \\
\hline & KI (X1) &, 013 & ,091 & ,013 & ,142 & ,888 \\
\hline & $\mathrm{KE}(\mathrm{X} 2)$ &, 140 & , 100 & ,161 & 1,405 & ,164 \\
\hline & KS (X3) &, 752 &, 135 & ,602 & 5,565 &, 000 \\
\hline
\end{tabular}

a. Dependent Variable: KWM (Y)

Tabel 4 hasil perhitungan dengan teknik regresi linier berganda menunjukan adanya pengaruh-pengaruh setiap variabel dengan melihat nilai koefisien beta $(\beta)$. Hasil regresi ini dapat dibentuk model persamaannya yaitu $Y=\mathbf{6 , 2 4 6}+\mathbf{0 , 0 1 3} X_{1}+$ $0,140 X_{2}+0,752 X_{3}+\varepsilon$.

Dengan melihat pada tabel 4 maka dapat diinterpreasikan bahwa pertama variabel kecerdasan intelektual memiliki signifikansi $\mathbf{0 , 8 8 8}>0,05$ dan nilai $t$ hitung $\mathbf{0 , 1 4 2}<\mathrm{t}$ tabel 1,993 serta $\boldsymbol{\beta}_{\mathbf{1}}$ bernilai $\mathbf{0 , 0 1 3}$, maka secara parsial variabel kecerdasan intelektual $\left(\mathrm{X}_{1}\right)$ berpengaruh tidak signifikan terhadap kinerja wirausaha muslim.
Kedua yaitu variabel kecerdasan emosional memiliki signifikansi $\mathbf{0 , 1 6 4}>0,05$ dan nilai t hitung $\mathbf{1 , 4 0 5}<\mathrm{t}$ tabel 1,993 serta $\boldsymbol{\beta}_{\mathbf{2}}$ bernilai 0,140, maka secara parsial variabel kecerdasan emosional $\left(\mathrm{X}_{2}\right)$ berpengaruh tidak signifikan terhadap kinerja wirausaha muslim.

Ketiga variabel kecerdasan spiritual memiliki signifikansi $\mathbf{0 , 0 0 0}<0,05$ dan nilai $\mathrm{t}$ hitung 5,565 $<\mathrm{t}$ tabel 1,993 serta $\boldsymbol{\beta}_{\mathbf{3}}$ bernilai $\mathbf{0 , 7 5 2}$, maka secara parsial variabel kecerdasan spiritual $\left(\mathrm{X}_{3}\right)$ berpengaruh secara signifikan terhadap kinerja wirausaha muslim.

Tabel 5

ANOVA

\begin{tabular}{|c|c|c|c|c|c|c|}
\hline \multicolumn{2}{|c|}{ Model } & $\begin{array}{l}\text { Sum of } \\
\text { Squares }\end{array}$ & Df & $\begin{array}{c}\text { Mean } \\
\text { Square }\end{array}$ & $\mathrm{F}$ & Sig. \\
\hline \multirow[t]{3}{*}{1} & Regression & 822,926 & 3 & 274,309 & 31,730 &, $000^{\mathrm{b}}$ \\
\hline & Residual & 708,900 & 82 & 8,645 & & \\
\hline & Total & 1531,826 & 85 & & & \\
\hline
\end{tabular}

a. Dependent Variable: KWM (Y)

b. Predictors: (Constant), KS (X3), KI (X1), KE (X2)

Berdasarkan tabel 5 di atas dapat diinterpretasikan bahwa variabel kecerdasan intelektual, kecerdasan emosional, dan, kecerdasan memiliki signifikansi $\mathbf{0 , 0 0 0}<0,05$ dan nilai $\mathrm{F}$ hitung 31,730 > F tabel 2,72, maka dapat disimpulkan bahwa secara simultan atau 
bersama-sama kecerdasan intelektual $\left(\mathrm{X}_{1}\right)$, kecerdasan emosional $\left(\mathrm{X}_{2}\right)$, dan kecerdasan spiritual $\left(\mathrm{X}_{3}\right)$ berpengaruh signifikan terhadap kinerja wirausaha muslim (Y).

Tabel 6

\begin{tabular}{|l|r|r|r|c|}
\hline & & & & Model Summary \\
Model & $\mathrm{R}$ & R Square & Adjusted R Square & $\begin{array}{c}\text { Std. Error of the } \\
\text { Estimate }\end{array}$ \\
\hline 1 &, $733^{\mathrm{a}}$ &, 537 &, 520 & 2,94026 \\
\hline
\end{tabular}

a. Predictors: (Constant), KS (X3), KI (X1), KE (X2)

Berdasarkan tabel 6 di atas, dapat diketahui bahwa nilai $\mathrm{R}$ square sebesar 0,537. Data visual ini menunjukan bahwa pengaruh variabel $\mathrm{X}_{1}, \mathrm{X}_{2}$, dan $\mathrm{X}_{3}$ terhadap variabel $\mathrm{Y}$ secara simultan adalah sebesar $53,7 \%$ dan sisanya sebesar $46,3 \%$ dipengaruhi oleh variabel lain yang tidak dijelaskan dalam penelitian ini.

\section{Kesimpulan}

Berdasarkan hasil pengujian hipotesis, maka dapat disimpulkan bahwa hasil penelitian ini menunjukan pertama secara parsial kecer-dasan intelektual dan kecerdasan emosional pengaruhnya tidak signifikan terhadap kinerja wirausaha muslim. Hanya kecerdasan spiritual yang berpengaruh signifikan terhadap kinerja wirausaha muslim. Kedua secara simultan me-nunjukan bahwa kecerdasan intelektual, kecer-dasan emosional, dan kecerdasan spiritual ber-pengaruh signifikan terhadap kinerja wirausaha muslim.

Berdasarkan kesimpulan di atas maka kinerja wirausaha muslim dipengaruhi oleh ketiga kecerdasan tersebut. Namun perlu diperhatikan bahwa kecerdasan spiritual bagi pengusaha muslim memiliki kontribusi besar

\section{Referensi}

Abdul Jalil. 2012. Spiritual Entrepreneurship

(Studi Transformasi pada Pengusaha

Kudus). Institut Agama Islam Negeri

Sunan Ampel Surabaya. bagi kesusksesan bisnisnya. Maka dari bagi pengusaha muslim perlu menjaga dan meningkatkan spiritualitas dirinya dalam segala aspek bisnis.

\section{Implikasi dan Limitasi}

Berdasarkan hasil penelitian dapat diketahui bahwa kecerdasan spiritual memiliki pengaruh yang paling besar terhadap kinerja wirausaha muslim di Kabupaten Purwakarta. Maka dari itu jika wirausaha muslim baik di level mikro maupun kecil ingin mencapai $A l$ Falah atau keberhasilan yang sesungguhnya dalam berbisnis maka perlu memiliki dan terus meningkatkan spiritualnya. Meskipun demikian, wirausaha muslim juga tetap harus memiliki kecerdasan intelektual dan emosional untuk menyeimbangi spiritualnya ditengah kondisi saat ini.

Penelitian ini memiliki ruang lingkup yang terbatas pada tiga variabel saja. Maka dari itu untuk penelitian selanjutnya perlu mengkaji dan me-ngembangkan variabel lainnya yang lebih luas dengan konsep Islam yang mendalam yang berkaitan dengan kemajuan kinerja wira-usaha muslim secara berkelanjutan.

Agus Yulianto. 2009. Al-Falah dan Al-Fauz dalam Al-Qur'an ; (Studi Ma'ani AlQur'an). Fakultas Ushuluddin Universitas Islam Negeri Sunan 
Kalijaga Yogyakarta : Tidak diterbitkan.

Aminuddin, Zanatul Shima, et al. 2016. Exploring the Concept of Al-Falah (Success) in Business ; An Insight from Muslim Expert.International Journal of Business and Applied Social Science Vol. 2, No. 8.

Ani Muttaqiyathun. 2010. Hubungan Emotional Quotient, Intellectual Quotient, Spiritual Quotient dengan Entrepreneur's Performance. Jurnal Manajemen dan Bisnis. Vol. 2, No. 3 : 221-234.

Antoni. 2014. Muslim Entrepreneurship : Membangun Muslimpreneur Characteristic dengan Pendekatan Knowledge Based Economy. Jurnal Pendidikan dan Kajian Islam Vol. 7, No. 2.

Aprijon. 2013. Kewirausahaan dan Pandangan Islam. Menara Vol. 12, No. 1 Januari-Juni 2013.

Ary Ginanjar Agustian. 2002. Rahasia Sukses Membangun Kecerdasan Emosi dan Spiritual. Arga : Jakarta.

Azalia. (31 Agustus 2015). Training Motivasi ESQ. (File Video). Diambil dari https://www.youtube.com/watch?v= SBh2y4DjW2c.

Dedeng Abdul Gani A. 2016. Entrepreneur Orientation in Islamic Perspective. Program Studi Manajemen STIE. DR. Khez Muttaqien Purwakarta. Dedeng.amrullah@gmail.com.

Dirk Malaga Kusuma. 2013. Kinerja Pegawai Negeri Sipil (PNS) di Kantor Badan
Kepegawaian Daerah Kabupaten

Timur. E-jurnal Administrasi Negara 1388-1400.

Djasuli, Mohamad. 2013. Pengaruh Kecerdasan Intelektual, Emosional, dan Spiritual terhadap Kinerja dengan Variabel Moderasi Kompetensi Di Kabupaten Lamongan. Universitas Trunojoyo Madura :djasuli@yahoo.com.

Endah Puspita Sari. 2016. Upaya Pemberdayaan Komunitas Melalui Sinergi Kader dan Psikolog Puskesmas. Vol. 4 No.1.

Goleman, Daniel. 1999. Kecerdasan Emosional. P.T. Gramedia : Jakarta.

http://dwihayulestari.blogspot.co.id/2014/02/p erbedaan-iq-sq-eq-dan-esq.html

Iqtishodia Jurnal Ekonomi Islam Republika, Kamis 22 Mei 2014.

Ita Nurcholifah. 2015. Membangun Muslim Entrepreneurship : dari Pendekatan Konvensional ke Pendakatan Syariah. Fakultas Syari'ah dan Ekonomi Islam IAIN Pontianak. Email :inurcholifah@yahoo.oc.id

Mahmood, Arshad and et al. 2015. Establishing Linkage between Intelligence, Emotional, Spiritual Quotient on Employees Performance in Governemnt Sector of Pakistan. Mediterranean Journal of Social Sciences Vol. 6, No. 6 S2 RomeItaly. 
Masoud, Taheri Lari, et al. 2012. Spiritual

Quotient and Entrepreneruship ; (A Case Study). Interdiclipinary Journal of Contemporary Research in Business Vol. 4, No. 5.

Muhaimin. Bisnis Wirausahawan Muslim Alabio : Studi Kasus di Kota Banjarmasin. Fakultas Syari'ah IAIN Antasari, Jl. A. Yani KM. 4,5 Banjarmasin. Email : muhaimin@iain.antasari.ac.id.

Nachiappan, Supiah, et al. 2013. Analysis of Cognition Integration in Intelligence (IQ), Emotional Quotient (EQ) and Spiritual Quotient in Transforming Cameron Highland Youth through Hermeunetics Pendagogy. Sultan Idris University, Tanjung Malim 35900 Malaysia, Elsevier Ltd.

Peter Garlans Sina. 2012. Pengaruh Kecerdasan Spiritual terhadap Pengelolaan Keuangan Pribadi. Jurnal Manajemen, Vol. 11, No. 2, Mei 2012.

Ridwan Saptoto. 2010. Hubungan Kecerdasan Emosi dengan Kemampuan Coping Adaptif. Jurnal Psikologi, Vol. 37, No. $1: 13-22$.

Sarita Permata Dewi. 2012. Pengaruh Pengendalian Internal dan Gaya Kepemimpinan terhadap Kinerja Karyawan SPBU yogyakarta ; (Studi Kasus pada SPBU Anak Cabang Perusahaan RB. Group). Jurnal Nominal Vol. 1, No. 1.

Sartono, Sawal, dkk. 2014. Analisis Pertumbuhan Kewirausahaan dan
Efektivitas Kelembagaan di

Kabupaten Tulung Agung. Jurnal Universitas Tulung Agung Bonorowo Vol. 2, No. 1.

Seun, A.O dan Kalsom, A.W. 2015. New Venture Creation Determinant Factors of Social Muslimpreneur. Pertanika Journal Social Science and Humanities 23 (S) : 17-32.

Sugiyono. 2015. Metode Penelitian Kuantitatif Kualitatif dan $R \& D$. Alfabeta : Bandung.

Thaib, Lukman dan Pa, Bharuddin Che. 2014. Islamic Business Leadership Modelling for Sustainable Development. International Journal of Multidiclipinary Academic Research Vol. 2, No. 1.

Tulus T.H. Tambunan. 2009. UMKM di Indonesia. Ghalia Indonesia : Bogor.

Wahab, Kalsom Abdul dan Rafiki, Ahmad. 2014. Measuring Small Firm Entrepreneur's Performance Based on Al Falah. World Applied Sciences Journal Vol. 29, No. 12 : 1532-1539.

Widodo. 2013. Model Peningkatan Kinerja UKM Berbasis Orientasi Entrepreneur. Jurnal Dinamika Manajemen Vol. 4, No. 2, : 204-219. Z. Heflin Frinces. 2010. Pentingnya Profesi Wirausaha Di Indonesia. Jurnal 
Ekonomi dan Pendidikan Vol. 7, No. 1.

Zin, Sakinah Mat dan Adnan, Ahmad Azrin. 2016. How Do Intellcetual Capital and Islamic Values Relate to Small

\section{Riwayat Penulis}

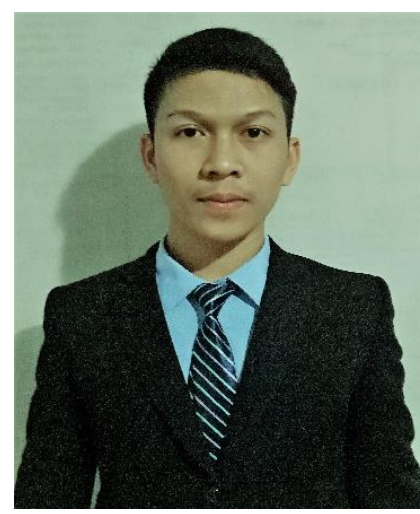

Nama Saya Ismail Ludin. Saya lahir di Purwakarta hari Sabtu 01 Mei 1994. Saya bertempat tinggal di Pasawahan Kabupaten Purwakarta. Saya lahir dari seorang ibu yang bernama Apong Yaya dan ayah Oban Sobandi. Saya anak yang ke empat dari lima bersaudara. Pada tahun 2007, Saya lulus sekolah dasar di

\author{
Business Performance? \\ A \\ Conceptual Framework. Journal of \\ Applied Environmental and \\ Biological Science 6 (3S) 42-49.
}

SDN Cidahu, tahun 2010 lulus di SMPN 3 Pasawahan, dan tahun 2013 lulus di SMAN 1 Pasawahan. Pada tahun 2013, Saya diterima di Sekolah Tinggi Ilmu Ekonomi DR. Khez. Muttaqien Purwakarta dengan Program Studi Manajemen.

Setelah menempuh empat jenjang pendidikan, saat ini Saya aktif mengajar bahasa Inggris di salah satu tempat kursus bahasa inggris di Purwakarta. Selain itu, Saya juga mengikuti beberapa kursus bahasa Inggris untuk tujuan mempersiapkan diri dan mencari beasiswa kuliah di luar negeri untuk program Magister. Kampus tujuan saya di Inggris yaitu Cambridge University. Program Studi yang akan Saya ambil adalah ilmu Ekonomi dan Manajemen Bisnis. 